\title{
UJI EFEK ANALGESIK EKSTRAK KULIT MANGGIS (GARCINIA MANGOSTANA L.) PADA MENCIT SWISS (MUSS MUSCULUS)
}

\author{
${ }^{1}$ Ripka Margaretha Ponggele \\ ${ }^{2}$ Johanis Najoan \\ ${ }^{2}$ Jane Wuisan
}

\author{
${ }^{1}$ Kandidat Skripsi Fakultas Kedokteran Universitas Sam Ratulangi \\ ${ }^{2}$ Bagian Farmakologi dan Terapi, Fakultas Kedokteran Universitas Sam Ratulangi \\ Email: Riaponggele@yahoo.co.id
}

\begin{abstract}
Background: Indonesia is the country with the second largest plants after Brazil. One of the plants that grow in Indonesia is the mangosteen plant is utilized as a medicine by the people of Indonesia but also by people in some other countries. Mangosteen skin is most often used to treat diseases such as fever, diarrhea, hypertension, antioksidant, antibiotics, anti-inflammatory, and many other diseases. This study aims to prove the presence or absence laboratorik analgesic effects of mangosteen peel extract in mice. Methods: This study uses a sample of nine experimental Swiss mice. The sample was divided into 3 groups, namely the positive control group given the drug tramadol, negative control group given distilled water control and experimental groups were given mangosteen peel extract, each group consisted of three mice. Testing is done by providing analgesic effects of pain stimuli using thermal stimuli (hot plate method) with a temperature of 550C. Given pain stimuli will cause the mice were protecting themselves by jumping response or lick the feet and tail. Testing efekan algesik done before giving the test substance and the reference solution, then at minute 30,60,90 and 120 minutes after administration of the test substance and the reference solution. Tests carried out for 1 minute.

Results: mangosteen peel extract has analgesic effects are starting to look at minute 30 to minute 120 with the maximum effect seen at minute 90. Conclusion: mangosteen peel extract (Garcinia mangostana, $L$ ) has analgesic effect in swiss mice (Mus musculus)
\end{abstract}

Keywords: Test the effects of analgesics, the mangosteen peel extract, mangosteen skin

\begin{abstract}
Abstrak: Indonesia merupakan negara yang mempunyai tumbuh-tumbuhan terbesar kedua setelah Brasil. Salah satu tumbuhan yang tumbuh di Indonesia adalah tanaman manggis yang sudah dimanfaatkan sebagai obat oleh penduduk Indonesia bahkan oleh penduduk di beberapa negara lain. Kulit manggis yang paling sering digunakan untuk mengobati penyakit seperti demam, diare, hipertensi, antioksidant, antibiotik, antiinflamasi, dan masih banyak penyakit lainnya. Penelitian ini bertujuan untuk membuktikan secara laboratorik ada tidaknya efek analgesik dari ekstrak kulit manggis pada mencit. Metode: Penelitian ini menggunakan metode eksperimental dengan sampel 9 ekor mencit Swiss. Sampel di bagi dalam 3 kelompok, yaitu kelompok kontrol positif yang diberikan obat tramadol, kelompok kontrol negatif diberikan aquades dan kelompok kontrol eksperimen yang diberikan ekstrak kulit manggis, yang masing-masing kelompok terdiri dari 3 ekor mencit. Pengujian efek analgesik dilakukan dengan memberikan rangsang nyeri menggunakan metode rangsang panas (hot plate method) dengan suhu $55^{\circ} \mathrm{C}$. Rangsang nyeri yang diberikan akan menyebabakan mencit melakukan perlindungan diri dengan respon melompat atau menjilat kaki dan ekor. Pengujian efek analgesik dilakukan sebelum pemberian zat uji dan larutan pembanding, kemudian pada menit ke 30,60,90 dan menit ke 120 setelah pemberian zat uji dan larutan pembanding. Pengujian dilakukan selama 1 menit. Hasil: Ekstrak kulit manggis mempunyai efek analgesik yang mulai terlihat pada menit ke 30 sampai menit ke 120 dengan efek maksimalnya terlihat pada menit ke 90 .
\end{abstract}

Simpulan: Ekstrak kulit manggis (Garcinia mangostana, L) memiliki efek analgesik pada mencit swiss (Mus musculus).

Kata Kunci: Uji efek analgesik, ekstrak kulit manggis, kulit manggis. 
Indonesia dikenal sebagai Negara yang mempunyai tumbuh-tumbuhan terbesar kedua setelah Brasil. Jenis tumbuhtumbuhan di Indonesia terdapat \pm 30.000 jenis dan diantaranya \pm 9.600 jenis termasuk tanaman obat. ${ }^{1}$ Salah satu tanaman obat yang tumbuh di Indonesia adalah manggis (Garcinia mangostana, L $)^{2}$ Manggis merupakan tanaman buah tropis yang berasal dari Malaysia yang kemudian berkembang juga di Indonesia. ${ }^{3}$

Penduduk Indonesia menggunakan kulit buah manggis sebagai bahan berkhasiat obat. Air rebusan kulit buah manggis digunakan untuk mengobati luka, demam, diare, sariawan, sembelit, serta penyakitpenyakit lain. ${ }^{4}$ Masyarakat Venezuela memanfaatkan kulit manggis untuk mengobati infeksi kulit akibat parasit sedangkan masyarakat Malaysia menggunakan kulit manggis untuk mengobati penyakit jantung, stroke, hipertensi. Masyarakat China, sejak zaman dahulu telah memanfaatkan kulit manggis sebagai obat diare. Penduduk di Negara lain seperti Filipina, Karibia, Brasil, Amerika Serikat, Australia, India dan Jepang juga mempercayai khasiat dari buah manggis tersebut. $^{5}$

Kulit buah manggis mengandung senyawa organik yaitu xanthone. Menurut Nuraini (2010) dan Putra (2012), xanthone dikenal sebagai antiinflamasi dan antioksidan yang sangat kuat dan diduga juga sebagai analgesik. ${ }^{6,7}$ Tetapi tidak ada pembuktian secara laboratorik. Berdasarkan hal tersebut maka dilakukan penelitianuntuk mengetahuiada tidaknya efek analgesik dari ekstrak kulit manggis pada mencit.

\section{METODE PENELITIAN}

Penelitian ini menggunakan metode eksperimental. Penelitian dilakukan di Laboratorium Farmakologi dan Terapi Fakultas Kedokteran Universitas Sam Ratulangi Manado. Penelitian dilakukan pada bulan Oktober 2012 sampai bulan Januari 2013. Penelitian ini menggunakan mencit swiss (Mus musculus) sebanyak 9 ekor sebagai hewan uji.
Hewan ini dibagi dalam 3 kelompok yang masing-masing terdiri atas 3 ekor, yakni:

1. Kelompuk I sebagai kelompok kontrol positif yang diberikan obat analgesik (Tramadol).

2. Kelompok II sebagai kelompok kontrol negatif yang diberikan aquades.

3. Kelompok III sebagai kelompok eksperimen yang diberikan ekstrak kulit manggis.

\section{Prosedur penelitian}

1. Proses ekstrkasi bahan dalam penelitian ini menggunakan metode maserasi dengan pelarut alkohol 95\%.

2. Hewan uji yang akan digunakan adalah mencit jantan (Mus musculus). Mencit yang akan digunakan dengan berat berkisar 20 gram sampai 30 gram. Sebelum perlakuan, mencit dipuasakan selama \pm 11 jam.

3. Penyiapan zat uji dan larutan pembanding

a. Kontrol Positif

Sebagai kontrol positif digunakan obat analgesik tramadol. Dosis tramadol yang digunakan oleh manusia dewasa adalah $100 \mathrm{mg} / 50$ $\mathrm{kg}$ BB. Tramadol dibuat dalam bentuk larutan dengan cara melarutkan $50 \mathrm{mg}$ bubuk tramadol dalam $50 \mathrm{ml}$ aquades. Konversi dosis pada manusia dengan berat $70 \mathrm{~kg}$ ke mencit 20 gram adalah 0,0026 (Laurence \& Bacharach, 1964).

Perhitungan dosis konversi untuk berat 50 kg adalah:

$50 \mathrm{~kg} \times 100 \mathrm{mg} \times 0,0026=$

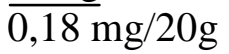

$70 \mathrm{~kg}$

0,18 mg tramadol dilarutkan dengan aquades hingga diperoleh $0,5 \mathrm{ml}$ yang akan diberikan pada kelompok perlakuan.

b. Kontrol negatif Untuk kontrol negatif, dipergunakan aquades. Pemberian aquades $0,5 \mathrm{ml} /$ $20 \mathrm{~g}$ mencit 
c. Ekstrak kulit manggis

Ekstrak kulit manggis yang telah dibuat, diambil sebanyak 1 gram kemudian dilarutkan dengan $10 \mathrm{ml}$ aquades. Diberi perlakuan pada mencit dengan volume pemberian $0,5 \mathrm{ml} / 20 \mathrm{~g}$ mencit, sehingga dosis yang diberikan kepada mencit sebanyak $50 \mathrm{mg}$.

1. Pemberian zat uji dilakukan per oral menggunakan semprit $1 \mathrm{ml}$ dan NGT pediatrik no. 3,5.

2. Pengujian efek analgesik

Mencit sebagai hewan uji, dimasukkan ke dalam beaker glass yang telah dipanaskan dalam water bath yang berisi air dengan suhu $55^{\circ} \mathrm{C}$.

Setelah mencit ada dalam water bath maka respon mencit diamati, yaitu dengan melihat berapa kali / frekuensi mencit menjilat kakinya atau melompat untuk menghindari nyeri selama 1 menit.

Mencit diberikan zat yang akan diuji dan larutan pembanding (obat tramadol dan aquades), kemudian mencit diistirahatkan untuk diamati kembali.

Pengamatan terhadap respon dari mencit dilakukan pada menit ke 30, 60, 90, 120 setelah pemberian zat uji dan larutan pembanding, dengan lama pengamatan 1 menit.

Pengamatan seluruhnya dilakukan sebanyak 5 kali, yaitu:

- Sebelum pemberian zat uji
- Menit ke-30 setelah pemberian zat uji

- Menit ke-60 setelah pemberian zat uji

- Menit ke-90 setelah pemberian zat uji

- Menit ke-120 setelah pemberian zat uji.

\section{HASIL}

Data di bawah ini adalah data yang diperoleh dengan menguji 3 kelompok mencit Swiss yang tiap kelompok terdiri dari 3 ekor mencit.

A. Kelompok I sebagai kelompok kontrol positif yang diberikan obat tramadol. Pengujian efek analgesik dilakukan sebelum dan sesudah diberikan tramadol. Hasil penelitian kelompok kontrol positif (tramadol) dapat di lihat pada Tabel 1 di bawah ini.

Pada Tabel 1, terlihat bahwa sebelum pemberian obat tramadol, jumlah respon mencit rata-rata 44 kali. Setelah pemberian obat pada menit ke 30, rata-rata jumlah respon menurun menjadi 20,7 kali (dibulatkan menjadi 20 kali), pada menit ke 60 menjadi 14,3 kali (dibulatkan menjadi 14 kali), pada menit ke 90 menjadi 8,7 kali (dibulatkan menjadi 8 kali) dan pada menit ke 120 rata-rata jumlah respon mencit menjadi 13 kali. Puncak penurunan jumlah respon rata-rata terhadap nyeri, terjadi pada menit ke 90 .

Tabel 1. Hasil Pengamatan Respon Kelompok Kontrol Positif (Tramadol)

\begin{tabular}{|c|c|c|c|c|c|c|c|c|c|c|c|c|c|c|c|}
\hline \multirow{4}{*}{ SUBJEK } & \multicolumn{15}{|c|}{ Jumlah Respon Mencit } \\
\hline & \multirow{2}{*}{\multicolumn{3}{|c|}{$\begin{array}{c}\text { Sebelum } \\
\text { Perlakuan }\end{array}$}} & \multicolumn{12}{|c|}{ Setelah Perlakuan (Pemberian Tramadol) } \\
\hline & & & & \multicolumn{3}{|c|}{30} & \multicolumn{3}{|c|}{60} & \multicolumn{3}{|c|}{90} & \multicolumn{3}{|c|}{120} \\
\hline & $\mathrm{L}$ & $\mathrm{J}$ & $\mathrm{T}$ & $\mathrm{L}$ & $\mathrm{J}$ & $\mathrm{T}$ & $\mathrm{L}$ & $\mathrm{J}$ & $\mathrm{T}$ & $\mathrm{L}$ & $\mathrm{J}$ & $\mathrm{T}$ & $\mathrm{L}$ & $\mathrm{J}$ & $\mathrm{T}$ \\
\hline I & - & 56 & 56 & - & 23 & 23 & - & 17 & 17 & - & 15 & 15 & - & 21 & 21 \\
\hline II & 1 & 38 & 39 & 1 & 21 & 22 & - & 15 & 15 & - & 9 & 9 & - & 15 & 15 \\
\hline III & 2 & 35 & 37 & - & 17 & 17 & - & 11 & 11 & - & 2 & 2 & - & 3 & 3 \\
\hline Jumlah & & & 132 & & & 62 & & & 43 & & & 26 & & & 39 \\
\hline Rata-rata & & & 44 & & & 20,7 & & & 14,3 & & & 8,7 & & & 13 \\
\hline
\end{tabular}

Keterangan : L = Lompat, $\mathrm{J}=$ Jilat, $\mathrm{T}=$ Total dari menjilat dan melompat 
Tabel 2. Hasil Pengamatan Respon Kelompok Kontrol Negatif (Aquades)

\begin{tabular}{|c|c|c|c|c|c|c|c|c|c|c|c|c|c|c|c|}
\hline \multirow{4}{*}{ SUBJEK } & \multicolumn{15}{|c|}{ Jumlah Respon Mencit } \\
\hline & \multirow{2}{*}{\multicolumn{3}{|c|}{$\begin{array}{l}\text { Sebelum } \\
\text { Perlakuan }\end{array}$}} & \multicolumn{12}{|c|}{ Setelah Perlakuan (Pemberian Aquades) } \\
\hline & & & & \multicolumn{3}{|c|}{30} & \multicolumn{3}{|c|}{60} & \multicolumn{3}{|c|}{90} & \multicolumn{3}{|c|}{120} \\
\hline & $\mathrm{L}$ & $\mathrm{J}$ & $\mathrm{T}$ & $\mathrm{L}$ & $\mathrm{J}$ & $\mathrm{T}$ & $\mathrm{L}$ & $\mathrm{J}$ & $\mathrm{T}$ & $\mathrm{L}$ & $\mathrm{J}$ & $\mathrm{T}$ & $\mathrm{L}$ & $\mathrm{J}$ & $\mathrm{T}$ \\
\hline I & 4 & 35 & 39 & 20 & 17 & 37 & 3 & 30 & 33 & 6 & 30 & 36 & 8 & 55 & 63 \\
\hline II & 3 & 32 & 35 & 1 & 85 & 86 & - & 66 & 66 & 2 & 48 & 50 & 4 & 27 & 31 \\
\hline III & - & 61 & 61 & - & 37 & 37 & 10 & 27 & 37 & 21 & 36 & 57 & 32 & 3 & 35 \\
\hline Jumlah & & & 135 & & & 160 & & & 136 & & & 143 & & & 129 \\
\hline Rata-rata & & & 45 & & & 53,3 & & & 45,3 & & & 47,7 & & & 43 \\
\hline
\end{tabular}

Keterangan : $\mathrm{L}=$ Lompat, $\mathrm{J}=$ Jilat, $\mathrm{T}=$ Total dari menjilat dan melompat

Tabel 3. Hasil Pengamatan Respon Kelompok Eksperimen (Ekstrak kulit manggis)

\begin{tabular}{|c|c|c|c|c|c|c|c|c|c|c|c|c|c|c|c|}
\hline \multirow{4}{*}{ SUBJEK } & \multicolumn{15}{|c|}{ Jumlah Respon Mencit } \\
\hline & \multirow{2}{*}{\multicolumn{3}{|c|}{$\begin{array}{l}\text { Sebelum } \\
\text { Perlakuan }\end{array}$}} & \multicolumn{12}{|c|}{ Setelah Perlakuan (Pemberian Ekstrak Kulit Manggis) } \\
\hline & & & & \multicolumn{3}{|c|}{30} & \multicolumn{3}{|c|}{60} & \multicolumn{3}{|c|}{90} & \multicolumn{3}{|c|}{120} \\
\hline & $\mathrm{L}$ & $\mathrm{J}$ & $\mathrm{T}$ & $\mathrm{L}$ & $\mathrm{J}$ & $\mathrm{T}$ & $\mathrm{L}$ & $\mathrm{J}$ & $\mathrm{T}$ & $\mathrm{L}$ & $\mathrm{J}$ & $\mathrm{T}$ & $\mathrm{L}$ & $\mathrm{J}$ & $\mathrm{T}$ \\
\hline I & - & 62 & 62 & - & 42 & 42 & - & 35 & 35 & - & 31 & 31 & - & 28 & 28 \\
\hline II & 4 & 60 & 64 & - & 27 & 27 & - & 15 & 15 & - & 2 & 2 & - & - & - \\
\hline III & 3 & 38 & 41 & 2 & 6 & 8 & 1 & - & 1 & 3 & - & 3 & 10 & - & 10 \\
\hline Jumlah & & & 167 & & & 77 & & & 51 & & & 36 & & & 38 \\
\hline Rata-rata & & & 55,7 & & & 25,7 & & & 17 & & & 12 & & & 12,7 \\
\hline
\end{tabular}

Keterangan : $\mathrm{L}=$ Lompat, $\mathrm{J}=$ Jilat, $\mathrm{T}=$ Total dari menjilat dan melompat

B. Kelompok II sebagai kelompok kontrol negatif yang diberikan aquades. Pengujian efek analgesik dilakukan sebelum dan sesudah diberikan aquades. Hasil penelitian kelompok kontrol negatif (aquades) dapat dilihat pada tabel 2 di bawah ini.

Pada Tabel 2 kelompok kontrol negatif di atas yang diberi aquades, menunjukkan rata-rata jumlah respon mencit sebelum pemberian aquades sebanyak 45 kali. Setelah pemberian aquades pada menit ke 30 , rata-rata jumlah respon mencit menjadi 53,3 kali (dibulatkan menjadi 53 kali), pada menit ke 60 menjadi 45,3 kali (dibulatkan menjadi 45 kali), pada menit ke 90 menjadi 47,7 kali (dibulatkan menjadi 47 kali) dan pada menit ke 120 rata-rata jumlah respon mencit menjadi 43 kali. Dari hasil di atas, menunjukan bahwa kelompok yang di beri aquades tidak menunjukan efek analgesiknya karena sampai dengan akhir pengujian masih menunjukan respon terhadap nyeri.

C. Kelompok III sebagai kelompok eksperimen yang diberikan ekstrak kulit manggis. Pengujian efek analgesik dilakukan sebelum dan sesudah diberikan ekstrak kulit manggis. Hasil penelitian kelompok eksperimen (ekstrak kulit manggis) dapat dilihat pada tabel 3 di bawah ini.

Pada Tabel 3 di atas, kelompok kontrol eksperimen yang diberi ekstrak kulit manggis terlihat adanya efek analgesik. Sebelum pemberian ekstrak kulit manggis, rata-rata jumlah respon mencit sebanyak 55,7 kali (dibulatkan menjadi 55 kali). Pada menit ke 30 setelah pemberian ekstrak kulit manggis, rata-rata jumlah respon mencit menurun menjadi 25,7 kali (dibulatkan menjadi 25 kali), pada menit ke 60 menjadi 17 kali, pada menit ke 90 menjadi 12 kali dan pada menit ke 120 menjadi 12,7 kali 
(dibulatkan menjadi 12 kali). Perbandingan grafik nilai rata-rata ketiga kelompok uji dapat dilihat pada Gambar 1 di bawah ini.

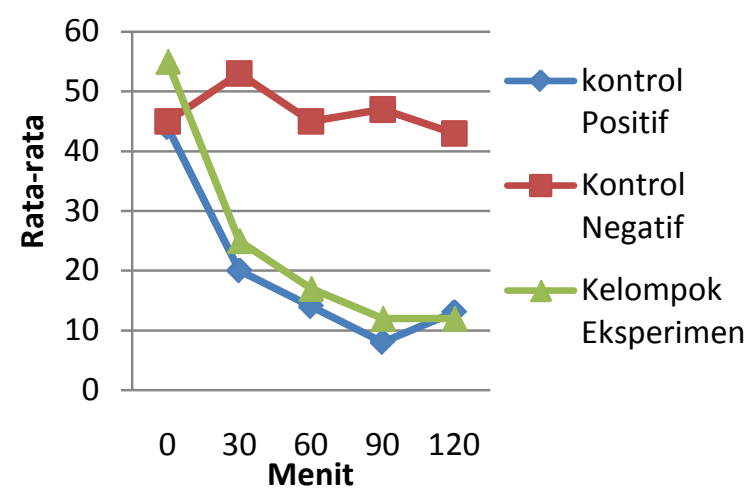

Gambar 1. Grafik perbandingan nilai rata-rata ketiga kelompok uji

\section{BAHASAN}

Penelitian ini dilakukan untuk melihat ada tidaknya efek analgesik dari suatu bahan terhadap hewan uji yang diberikan rangsang nyeri. Rasa nyeri disebabkan oleh rangsangan mekanik atau kimiawi, panas atau listrik yang dapat menimbulkan kerusakan jaringan dan melepaskan zat yang disebut mediator nyeri.Pada penelitian ini, rangsang nyeri yang diberikan menggunakan metode rangsang panas (hot plate method) dengan suhu $55^{\circ} \mathrm{C}$. Rangsang panas yang diberikan menyebabkan hewan uji melakukan perlindungan diri dengan respon menjilat kaki dan atau melompat.,9

Hewan uji yang digunakan adalah mencit Swiss (Mus musculus) jantan dan betina sebanyak 9 ekor dengan berat ratarata 20 gram sampai 30 gram. Mencit dibagi dalam 3 kelompok yaitu kelompok kontrol positif yang diberikan obat tramadol, kelompok kontrol negatif diberikan aquades dan kelompok eksperimen diberikan ekstrak kulit manggis. Masing-masing kelompok terdiri dari 3 ekor mencit. Sebelum perlakuan, masing-masing mencit dipuasakan selama kurang lebih 11 jam. Jumlah respon mencit terhadap rangsangan nyeri diamati sebelum pemberian zat uji, agar dapat dilihat perbandingan antara sebelum dan setelah pemberian zat uji. Adanya efek analgesik dari zat uji, akan mengurangi jumlah respon mencit terhadap rangsangan nyeri.

Dalam penelitian ini, telah dilakukan uji efek analgesik dengan menggunakan ekstrak kulit manggis sebagai kelompok eksperimen. Berdasarkan hasil pengujian pada kelompok eksperimen didapatkan penurunan respon mencit terhadap rangsang nyeri. Sebelum pemberian ekstrak kulit manggis, jumlah rata-rata respon mencit yang diberi rangsang nyeri adalah 55 kali. Setelah mencit diberikan ekstrak kulit manggis, pada menit ke 30 terjadi penurunan respon mencit menjadi 25 kali. Respon mencit terhadap nyeri terus menurun pada menit ke 60 menjadi 17 kali, pada menit ke 90 menjadi 12 kali dan pada menit ke 120 respon mencit menjadi 12 kali. Dari hasil tersebut, dapat dilihat bahwa ekstrak kulit manggis mempunyai efek analgesik. Efek analgesik pada ekstrak kulit manggis sudah terlihat dari menit ke 30 dan terus memberi efek pada menit ke 60 dan menit ke 90. Pada menit ke 120 efek analgesik dari ekstrak kulit manggis masih terlihat.

Pengujian pada kelompok kontrol positif dengan menggunakan obat analgesik yaitu tramadol, didapatkan bahwa pada menit ke 30 setelah pemberian obat tramadol terjadi penurunan respon mencit dari 44 kali menjadi 20 kali, pada menit ke 60 menjadi 14 kali dan mencapai puncak analgesiknya pada menit ke 90 yaitu respon mencit menjadi 8 kali. Pada menit ke 120 efek analgesiknya mulai menurun, di mana respon mencit meningkat menjadi 13 kali yang sebelumnya adalah 8 kali.

Berdasarkan hasil penelitian pada kontrol positif, efek analgesik obat tramadol pada mencit dengan pemberian secara oral, mulai timbul pada menit ke 30 dan mencapai puncak pada menit ke 90. Sedangkan pada manusia, efek analgesik tramadol setelah penggunaan secara oral timbul dalam 1 jam dan mencapai puncak dalam 2-3 jam. ${ }^{10}$ Hal ini terjadi karena perbedaan metabolisme obat antara manusia dengan mencit. ${ }^{11}$

Hasil penelitian diatas, dapat terlihat bahwa cara kerja dari ekstrak kulit manggis dan tramadol memiliki cara kerja yang 
sama. Pada kelompok kontrol pemberian ekstrak kulit manggis dan tramadol terlihat efek analgesiknya mulai dari menit ke 30. Kedua zat ini juga mencapai efek analgesik maksimalnya pada menit ke 90. Meskipun kedua zat uji tersebut yaitu ekstrak kulit manggis dan tramadol mencapai efek maksimalnya pada menit ke 90, pada menit ke 120 kedua zat ini juga masih memperlihatkan efek analgesiknya.

Hasil pengujian yang di dapatkan pada kelompok kontrol negatif yang diberikan aquades adalah jumlah rata-rata respon mencit terhadap nyeri cenderung stabil pada setiap waktu pengamatan. Jumlah rata-rata respon mencit sebelum pemberian aquades adalah 45 kali dan pada 30 menit setelah pemberian aquades, respon mencit meningkat menjadi 53 kali. Pada menit ke 60 , respon mencit menjadi 45 kali, pada menit ke 90 menjadi 47 kali dan pada menit ke 120 respon mencit menjadi 43 kali. Walaupun pada menit ke 120 respon mencit menurun dari 47 kali menjadi 43 kali, tetapi tidak terlihat adanya penurunan respon mencit terhadap rangsangan nyeri yang bermakna. Oleh karena itu, dapat disimpulkan bahwa aquades tidak memiliki efek analgesik.

\section{SIMPULAN}

Dari penelitian yang dilakukan dengan menguji efek analgesik ekstrak kulit manggis pada mencit Swiss dengan konsentrasi $10 \%$, dapat di simpulkan bahwa ekstrak kulit manggis mempunyai efek analgesik pada mencit Swiss.

\section{SARAN}

Perlu dilakukan penelitian lebih lanjut tentang efek analgesik ekstrak kulit manggis dengan menggunakan dosis yang berbeda, perlu dilakukan penelitian lebih lanjut untuk identifikasi dan isolasi zat berkhasiat dalam kulit manggis yang memiliki efek analgesik, perlu dilakukan penelitian efek analgesik ekstrak kulit manggis dengan waktu pengujian yang lebih lama dan dengan jumlah sampel yang lebih banyak.

\section{UCAPAN TERIMA KASIH}

Ucapan terima kasih disampaikan pada dr. Henoch Awaloei, MSc, SpFK dan dr. Christy Mambo MScserta semua pihak yang secara langsung maupun tidak langsung telah menumbuhkan ide atau gagasan dalam pemikiran penulis sehingga dapat menyelesaikan artikel ini.

\section{DAFTAR PUSTAKA}

1. Panjaitan R. Kebijakan Obat Tradisional Nasional Tahun 2007. Jakarta : Departemen Kesehatan;2007. h:14.

2. Tjahjaningtyas. Manggis Ratu Buah Kaya Manfaat Khasiat Dahsyat dan Tips Mengkonsusmsinya. Cetakan 1. Surabaya : Penerbit Stomata;2011. h: 2-56.

3. Warisno S, Dahana. K. Kulit Manggis Hidup Sehat Berkat Sang Ratu yang Berkhasiat. Jakarta: PT Gramedia Pustaka Utama;2012. h: 2-22

4. Hartanto SB. Mengobati Kanker dengan Manggis. Cetakan 1. Jogjakarta : Second Hope;2011. h: 12-15;29-45

5. Shabella R. Terapi Kulit Manggis. Cetakan 1. Jogjakarta : Galmas Publisher;2011. h: 35-37

6. Nuraini DN. Aneka Manfaat Kulit Buah dan Sayuran. Ed I. Yogyakarta:ANDI;2010 h:99-07

7. Putra SR. Rahasia-Rahasia Keajaiban Kulit Buah Manggis. Cetakan 1. Jogjakarta : DIVA Press;2012. h: 36-37

8. Nirmala S, Arun S, Bathula N, Sivanagamoorthi M, Ravichandiran V. Antioxidant (In vitro) and Analgesic Activity (In vivo) of Tannin Fraction of Stem Bark of Ficus racemosa Linn. India: School of Pharmaceutical Sciences, Vels University;2012.

9. Vogel HG. Drug Discovery and Evaluation: Pharmacological Assays. $2^{\text {nd }}$ edition. Jerman: Springer;2002. p:696.

10. Dewoto HR. Analgesik Opioid dan Antagonis. Dalam : Farmakologi dan Terapi. Ed 5. Jakarta: Balai Penerbit FKUI;2008. h:210-11;228

11. Gibson GG, Skett P. Pengantar Metabolisme Obat. Jakarta: Penerbit Universitas Indonesia;2006. h:120-82 